\title{
PENGALAMAN MENYUSUI EKSKLUSIF PADA IBU BEKERJA DI PESURUNGAN LOR KOTA TEGAL
}

\author{
Ulfatul Latifah $^{1)}$, Seventina Nurul Hidayah ${ }^{1)}$, Meyliya Qudriani ${ }^{3)}$ \\ e-mail: ulfatul.bidan@poltektegal.ac.id \\ Program Studi D III Kebidanan Politeknik Harapan Bersama \\ J1.Mataram no.09 Pesurungan Lor Kota Tegal
}

\begin{abstract}
Abstrak
Menyusui adalah tugas yang sangat wajar dan mulia dari seorang ibu serta salah satu ekspresi cinta seorang ibu. Tidak semua ibu menyusui dapat melewati tugas tersebut dengan baik karena berbagai kondisi salah satunya karena ibu bekerja. Penelitian ini bertujuan menganalisis faktor-faktor yang mempengaruhi penerapan ASI eksklusif pada ibu yang bekerja di Kelurahan Pesurungan Lor , untuk sukses melaksanakan ASI eksklusif dan berhasil mengatasi masalah-masalah serta hambatan dalam pelaksanaannya.

Penelitian ini bersifat kualitatif dengan pendekatan fenomenologi. Jumlah informan 3 orang ibu menyusui yang berada di wilayah Kelurahan Pesurungan Lor. Hasil wawancara pada informan didapatkan informasi tentang berbagai perasaan, persepsi, pemahaman dan pengetahuan ibu tentang menyusui, motivasi menyusui, bagaimana praktik menyusui secara eksklusif, hambatan-hambatan yang ditemukan dan dukungan yang diharapkan selama bekerja. Dengan informasi ini dapat dijadikan acuan bagi peneliti di dalam memberikan konseling menyusui bagi ibu yang bekerja mulai dari antenatal sampai postnatal. Bagi pemerintah dapat digunakan sebagai bahan evaluasi keberhasilan program menyusui sehingga dapat memberikan kontribusi terhadap peningkatan cakupan pemberian ASI secara eksklusif pada bayi untuk mencapai pertumbuhan perkembangan dan kesehatan optimal di Wilayah Kelurahan Pesurungan Lor Kota Tegal
\end{abstract}

Kata Kunci : Pengalaman menyusui, ASI Eksklusif, Ibu Bekerja

\section{Pendahuluan}

Menyusui adalah suatu proses alamiah yang besar artinya bagi kesejahteraan bayi, ibu, dan keluarga. Namun sering ibu-ibu tidak berhasil menyusui atau menghentikan menyusui lebih dini. Banyak alasan yang dikemukakan oleh ibu-ibu yang tidak menyusui bayinya antara lain ibu bekerja dan kurangnya dukungan dari keluarga. Oleh karena itu ibu-ibu memerlukan bantuan agar proses menyusui lebih berhasil. ${ }^{[1]}$

Berdasarkan data yang diperoleh, cakupan ASI Eksklusif di Kota Tegal tahun 2013 sebesar $49,55 \%$ meningkat dibandingkan tahun 2012 sebesar 38,89\%. Tetapi masih dibawah cakupan nasional sebesar $80 \%$. Cakupan ASI Eksklusif tertinggi ada di Puskesmas Tegal Barat sebesar 66,7\% sedangkan cakupan terendah di Puskesmas Tegal Selatan sebesar 35,1\%. Sedangkan di Puskesmas Margadana pada tahun 2013 urutan terendah ke 2 sebesar $36,2 \%$.

Mayoritas pekerjaan ibu di Kelurahan Pesurungan Lor yaitu bekerja sebagai pedagang dan di perkantoran/pabrik ataupun di tempat lain yang memerlukan waktu lama untuk meninggalkan bayinya mendapatkan kesulitan dalam penyusuan bayinya dan berusaha untuk dapat memberikan ASI kepada bayinya hingga 6 bulan, namun banyak diantara mereka dengan terpaksa harus menghentikan penyusuan bayi dan menggantikan ASI dengan susu formula. Hal tersebut diperkirakan berdampak pada profil kesehatan bayi yang diperoleh dari data statistik Dinas Kesehatan Kota Tegal dimana Angka Kematian Bayi (AKB) di Kota Tegal dalam 5 tahun terakhir (2009 - 2013) mengalami fluktuasi dimana tahun 2010 - 2012 terus mengalami peningkatan, diantaranya disebabkan oleh status gizi. ${ }^{[2]}$ Kondisi tersebut layak mendapatkan perhatian dan tenaga kesehatan khususnya tenaga bidan.

\section{Metode Penelitian}

Penelitian ini menggunakan metode kualitatif dengan pendekatan fenomenologi. Informan dipilih dengan metode purposif sejumlah 3 orang ibu menyusui. Sebagai pertimbangan etik partisipan secara sukarela 
telah menandatangani Informed Consent (self determination), dijaga kerahasiaan identitasnya selama dan sesudah penelitian (privacy), semua partisipan diperlakukan sama dengan mengganti nama partisipan dengan kode atau nomor (anonymity), serta dijaga kerahasiaan informasinya (confidentiality). Selama pengambilan data peneliti telah berusaha untuk memberi kenyamanan pada partisipan dengan mencari tempat/ruang yang nyaman selama memberi informasi (protection from discomfort ). ${ }^{[3]}$

Pengumpulan data dilakukan dengan cara wawancara mendalam dengan mengkaji isu sentral dari struktur utama subyek kajian dari para partisipan. Untuk meningkatkan ketepatan pengumpulan data dan menjamin pencapaian hasil yang komprehensif dari deskripsi tentang pengalaman dari partisipan, peneliti menggunakan teknik wawancara terbuka dan mendalam, merekam wawancara dan membuat catatan lapangan. Untuk menghindari subyektifitas, peneliti menggunakan teknik triangulasi sumber. Rancangan wawancara yang dibuat peneliti berguna untuk mendapatkan data berbagai perasaan dan pikiran informan yang berkaitan dengan pengalaman menyusui bayi selama 6 (enam) bulan pertama setelah kelahiran. Pada pertemuan pertama para informan telah diwawancarai dan direkam atas ijin dari informan. Kemudian hasil wawancara tersebut dibuat dalam bentuk suatu transkrip wawancara yaitu dalam bentuk deskripsi tekstual yang digunakan dalam analisis data.

\section{Hasil dan Pembahasan}

Karakteristik enam responden yang bersedia dilakukan wawancara antara lain sebagai berikut :

a. Informan Utama

1) Informan Utama 1 (IU1) : adalah Ny. $\mathrm{H}$ berusia 28 tahun pendidikan DIV Statistik pekerjaan Pegawai Badan Pusat Statistik (BPS) Slerok

2) Informan Utama 2 (IU2) : adalah Ny. $\mathrm{U}$ berusia 27 tahun pendidikan S1 PAI pekerjaan Guru

3) Informan Utama 3 (IU3) : adalah Ny. $\mathrm{T}$ berusia 26 tahun pendidikan $\mathrm{S} 1$ Pendidikan Ekonomi lama kerja 2 tahun sebagai guru di SD margadana 6

b. Informa Triangulasi

1) Informan Triangulasi 1 : pimpinan tempat kerja dari IU 1

2) Informan Triangulasi $2:$ pimpinan tempat kerja dari IU 2

3) Informan Triangulasi 3 : pimpinan tempat kerja dari IU 3

\section{Pengetahuan ibu tentang pentingnya ASI Eksklusif}

Pengetahuan tentang pentingnya ASI eksklusif diungkapkan informan sebagai berikut :

1) Pengertian, manfaat, pentingnya ASI, teknik menyusui yang benar, pencegahan puting susu lecet, tanda bayi cukup ASI

Pengetahuan informan tentang ASI eksklusif sebagian besar mengatakan bahwa ASI eksklusif adalah pemberian ASI selama 6 bulan tanpa makanan tambahan lain sekalipun susu formula. Satu informan mengatakan bahwa masih dikatakan ASI eksklusif jika diberikan obat kalau memang diperlukan untuk penyembuhan anak sakit (IU 3).

Pernyataan informan tersebut sejalan dengan Peraturan Pemerintah Nomor 33 Tahun 2012 Bab I Pasal 1 Ayat 2, pengertian ASI eksklusif adalah ASI yang diberikan kepada bayi sejak dilahirkan sampai usia enam bulan tanpa menambahkan dan mengganti dengan makanan atau minuman lain, kecuali suplemen vitamin, obat, dan mineral. ${ }^{[4]}$

Semua informan telah mengetahui pentingnya ASI Eksklusif yaitu salah satunya untuk kekebalan tubuh bayi dan kecerdasan otak (IU 1 -3)

Informan sebanyak dua orang mengetahui bahwa pencegahan puting susu lecet adalah dengan mengoleskan air susu pada puting ibu (IU 1, IU 2), sebagian informan lainnya menyatakan pencegahan puting susu lecet dengan air hangat, baby oil dan dengan menggunakan salep (IU 3)

Secara umum informan telah mengetahui tanda bayi cukup ASI, di- 
antaranya adalah pada saat menyusu bayi akan melepas puting sendiri, bayi tidurnya nyenyak, BAB berwarna kuning serta lengket ada ampasnya (IU 1), bayi tidak rewel (IU 2, IU 3)

Terkait pengetahuan tentang ASI eksklusif, sebanyak dua informan mendapat informasi langsung dari bidan tempat periksa selama kehamilan (IU 1, IU 2) satu informan mendapat informasi tidak langsung yaitu dari leaflet yang dipajang di tempat periksa bidan (IU3)

Pengetahuan ibu merupakan faktor yang dapat mempengaruhi pemberian ASI eksklusif. Hal ini sejalan dengan hasil penelitian Rahmawati (2010) dan Juliani (2009) yang menyatakan bahwa ada hubungan antara pengetahuan ibu dengan pemberian ASI eksklusif. Dengan pengetahuan yang baik informan akan memberikan bayinya ASI secara eksklusif sehingga ASI akan lancar dan bayi puas/cukup mendapat ASI, sehingga ibu tidak memberikan makanan tambahan selain ASI sebelum berumur 6 bulan. ${ }^{[5,6]}$

2) Pandangan ibu tentang tanggung jawab dalam memberikan ASI eksklusif yang merupakan hak bayi

Pandangan ibu bahwa ASI merupakan hak bayi, sejalan dengan dasar hukum Undang-undang Dasar pasal 28B ayat (2) bahwa setiap anak berhak atas kelangsungan hidup, tubuh dan berkembang serta berhak atas perlindungan dari kekerasan dan diskriminasi. Maknanya hak atas tumbuh dan berkembang salah satunya dengan mendapatkan ASI. ${ }^{[7]}$

Semua informan mengungkapkan bahwa menyusui sangat penting untuk kesehatan bayi, hal ini sejalan dengan teori yaitu ASI memegang peranan untuk meningkatkan kekebalan tubuh bayi. $^{[8]}$

3) Pandangan ibu terhadap susu formula terhadap tumbuh kembang anak

Informan Utama 1 (IU 1) mengungkapkan bahwa bayi tidak perlu diberi susu formula sampai dengan 6 bulan karena pencernaan belum siap, apabila ibu menyusui diberi kelebihan dengan produksi ASI yang cukup maka harus dimanfaatkan sebaik-baiknya untuk tumbuh kembang anak.

Informan lain menyampaikan bahwa ASI dapat menaikkan berat badan, baik untuk tumbuh kembang bayi. Selagi masih ada atau ASI masih cukup formula tidak mempunyai manfaat sampai 6 bulan (IU 2, IU 3)

Ungkapan informan di atas sejalan dengan teori Khamzah (2012) bahwa pemberian Asi merupakan hal penting dalam tumbuh kembang anak karena di dalam ASI terdapat kandungan minyak omega 3 asam linoleat alfa yang sangat dibutuhkan bagi perkembangan anak dan tidak terdapat pada susu formula. ${ }^{[9]}$

4) Masalah yang berkaitan dengan pemberian ASI eksklusif terutama selama ibu bekerja dalam bulan 1, apakah ada pengaruhnya atau tidak dalam penerapan ASI eksklusif.

Sebagian besar informan memiliki motivasi yang kuat, perasaan senang dan bangga karena dapat menyusui bayinya sendiri. Hal ini sesuai teori dari Abdullah 2004, bahwa menyusui anak merupakan bagian dari tugas biologi seorang ibu, dengan perasaan senang dan bangga bisa menjadi bagian dari konsep diri ibu yang positif sehingga ibu dapat berperan optimal dalam perawatan bayinya ${ }^{[10]}$.

\section{Pengetahuan ibu tentang ASI perah}

1) Usaha yang dilakukan ibu agar produksi ASI nya tetap banyak

"makan sayur yang ada kuahnya, kayak sayur asem, sop, terus nyusuin tiap 2 jam, tapi anak saya kalo belum 2 jam aja udah minta susu, tapi kalo tidur ya dibangunin..." (IU 1)

"makan banyak, ga usah mikir yang bikin stres, dibuat santai aja kalo ada masalah... soalnya ngaruh ke ASI... sering nyusuin tiap 2 jam... paling itu $m b . . . "(I U 2)$

"ya makan bergizi mb....susu saya juga sering.... sayur-sayuran yang hijau, minum yang banyak...." (IU 3)

2) Persiapan pemerahan ASI dan alat yang digunakan untuk memerah ASI sebelum ibu kembali bekerja 
" botol, pompa ASI, tas, sama es nya" (IU 1)

"yang disiapin ya tas, pompa, botol kaca, es batunya” (IU 2)

"tas, pompa electrik, plastik tempat ASI, es gel nya" (IU 3)

3) Mengajarkan ibu tentang cara memerah ASI dan menyimpan yang benar.

Menggali informasi tentang penerapan ASI perah dan kesulitannya selama bekerja

1) Praktik pemberian ASI yang disimpan

"Kalo mau diminumkan diturunin dulu ke kulkas yang bawah...nanti kalo udah ga terlalu beku baru dikeluarin terus dicelupin ke wadah yang ada air hangatnya habis itu diminumkan pake dot biar gampang..dulu sih saya seringnya pake air panas langsung..tapi kata temen saya ga boleh..."(IU 1)

"Ya dicelupin ke air hangat..yang agak banyak air hangatnya... soalnya kalo cuma dikit lama cairnya... biasanya sambil nunggu cair anak saya dioyongoyong dulu sama mertua biar nggak nangis, hee....nanti kalau sudah anget baru diminumkan dengan menggunakan dot, kalau pakai cangkir repot, tapi anak saya mau kok walaupun setelah minum pake dot kalau saya pulang juga tetep mau nyusu saya..."(IU 2)

"Asi yang tanggal nya lama dulu yang diminumkan..kalo besoknya mau diminumkan biasanya yang asi di freezer sore udah saya taruh di kulkas yang bawah, paginya kan udah mencair, nanti tinggal dicelupkan ke air hangat beberapa kali kalo udah anget langsung diminumin pake dot ..."(IU 3)

Semua informan mengungkapkan bahwa cara mereka menerapkan pemberian ASI perah adalah ASI yang beku semalaman di turunkan dulu ke kulkas yang bawah atau suhu rendah, kemudian pada saat akan disusukan ASI di celupkan dalam wadah yang berisi air hangat smpai suhunya pas, lalu baru diberikan dengan menggunakan dot. Ungkapan informan kurang sejalan dengan teori Auditya 2011, bahwa pemberian ASI perah sebaiknya jangan menggunakan dot, melainkan disuapi menggunakan sendok atau cangkir, karena dikhawatirkan bayi akan bingung puting dan akan menolak menyusu langsung dengan ibunya. Namun kondisi bingung puting tidak dialami oleh semua informan, seperti yang disampaikan oleh IU 6 bahwa pada awal kerja, ibu berusaha menyempatkan waktu untuk pulang jam 10 atau pada saat jam istirahat jadi bayi tetap mau menyusu ibunya walaupun diselingi dengan minum ASI perah menggunakan dot. ${ }^{[11]}$

\section{Penerapan ASI Eksklusif saat ibu bekerja}

" saya tetap bisa berikan ASI selama bekerja, ya paling lebih capek...kalo malam nyusui sambil merah asi juga, tapi kalo malam bancar kok mb... sebotol gitu cepet, kalo ditempat kerja saya merahnya di tempat sholat tapi kadang 3 ato 4 jam baru bisa merah... ya udah kebiasaan ya biasa saja.... kadang juga ga sempet...susu saya udah mrengkel, tapi ga sering..." (IU 1)

"ya asi disedot tiap kerja mb...tapi kadang kalau lagi sibuk saya bingung... kan biasanya susunya udah keras jadi tidak nyaman.... terus kadang saya bilang ke teman saya kalau mau nyedot ASI, nanti di ruang yang kosong saya meresnya disitu... tapi kurang nyaman kan keburu buat kerja lagi....tapi ya minimal dapat sebotol sih bisa..." (IU 2)

" hehehe....saya kadang pulang mba.... langsung nyusuin anak...nanti balik lagi kerja... tapi saya juga tetap nyediain penyedot ASI barangkali ga bisa pulang ya nyedot disana... ada sih ruang yang kosong hanya saja kan nyusuin cuma saya jadi kadang ga enak aja sama teman...padahal temen saya dukung semua....yang penting niat ga papa...." (IU 3)

\section{Dukungan pimpinan tempat kerja selama penerapan ASI Eksklusif}

"kalau dukungan kepala saya paling ya kalau pas saya ijin buat nyedot ASI diijinkan... tapi dukungan tempat atau yang lainnya belum" (IU 1) 
"fasilitas menyusui yang ga ada mba.... ya paling saya kalau nyedot digudang.... kulkas juga ga ada.... masih bersyukurnya sih kalau udah tau saya mau nyedot teman-teman saya pengertian... pimpinan juga ga masalah...."(IU 2)

"dukungan ya cuma mendukung gitu aja mb... maksudnya mempersilahkan barangkali mau nyedot asi ... tapi ruangannya itu yang masih minim.... ya saya mengandalkan cooler bag aja.... ibaratnya itu kulkasnya.... kan dingin ada es nya...." (IU 3)

\section{Mekanisme pertahanan terhadap} pengaruh susu formula dan MP ASI Dini

"saya setiap beberapa jam yang penting mompa....yang ngasih ASI perahnya kan sama mertua...nanti sebelum saya berangkat ASI misal jumlahnya 3 botol yang saya keluarin buat hari ini ya nanti harus kembali ke kulkas sejumlah itu...heheh...buat penyemangat aja mb.....biar ga habis....jadi barangkali pas saya perginya agak lama masih ada persediaan banyak.....formula ga usah dulu kata saya...ASI saya juga masih cukup "(IU 1)

"Masih mba... dedeknya sekarang mimiknya banyak banget... mungkin dah mulai laper kali ya mba.... kan bentar lagi udah makan.... makanya yang penting saya nya makan yang banyak.... kalau nggak kayak kemarin,,,, rasane les-les an kayak mau pingsan..... saya tetep minum pil pelancar ASI mba... biar tetap banyak..... eman-eman...."(IU 2)

" masih mba..hehehe.... cuma kemarin pompa ASI saya gosong.... kan direbus tapi kelupaan padahal cuma ditinggal nyapu aja... payah iz mba... tapi ni mau beli lagi... kata ibu saya wes lah ga usah beli lagi kan udah mau makan.... tapi sayanya ga mau... besok kalo susu saya mrengkel pas kerja atau pas lagi pergi malah repot... jam 10 an aja baju saya kadang udah basah... saya belum pengen ngasih susu formula... anak saya kayane mbuh-mbuhan gelem mba.... kan ga pernah dicoba " (IU 3)

\section{Keberhasilan penerapan ASI eksklusif}

"iya mba...perasaan saya banggaa, Alhmdulillah ya kurang 2 hari lagi brati anak saya berhasil dikasih asi eksklusif... suka dukanya pasti ada, kalo menurut saya yang bikin berhasil ya karena niatnya dulu, terus dukungan, walaupun kadang ada yang nyuruh dedenya dikasih makan yang penting kitanya jangan... mertua walaupun awalnya ga setuju tapi lama kelamaan juga ga masalah, pas kerja juga kadang kebentur jam kerja yang sibuk tapi bisa lah disempetin nyedot bentar pas udah agak senggang, walaupun ruangan yang memadai ga ada yang penting nyari ruang kosong atau musholla. Tapi kalo bisa jangan pas waktu sholat...kalo pas waktu sholat biasanya ada cowok yang masuk juga ga enak..."(IU 1)

"alhamdulillah diberi kelancaran mb.... dibantu mbak-mbaknya juga... makasih.... Sejak hamil ini prinsipku sudah harus ASI eksklusif ga pengen ditambahin apapun sebelum waktunya... jadinya walaupun ada hambatan alhamdulillah bisa dijalani mb..... memang berat.... tapi barangkali jadi investasi nanti kalau anak udah besar ya mba..." (IU 3)

Beberapa dari informan triangulasi mengatakan bahwa cuti yang yang diberikan bagi ibu yang melahirkan antara 2,5 - 3 bulan. Hal ini sejalan dengan teori Astuti 2007 bahwa dukungan tempat bekerja terhadap ibu menyusui dapat berupa pemberian cuti dengan waktu yang memadai. ${ }^{[12]}$

Dari pernyataan semua informan juga mengatakan bahwa di tempat kerja masih kurang memfasilitasi ibu yang akan memerah ASI. Kurangnya fasilitas dari tempat kerja yang menjadikan para ibu kesulitan untuk bisa memerah ASI secara leluasa karena tidak adanya ruang khusus dan lemari pendingin atau fasilitas. Fasilitas sangat dibutuhkan oleh para ibu karena membantu pemberian ASI secara eksklusif karena tempat yang nyaman akan membuat ibu menjadi rileks dengan kondisi ibu yang rileks maka produksi ASI akan meningkat. Fasilitas toilet atau gudang yang biasa untuk tempat ibu memerah ASI bukanlah ruangan 
bersih. ASI yang diperah beresiko terkena virus atau kuman toilet padahal saat memerah susu harus berada pada kondisi yang bersih, steril dari berbagai penyakit.

Berdasarkan hasil penelitian yang sudah peneliti dapatkan dapat disimpulkan ada 4 tema yang tersusun dalam penelitian ini yaitu pengetahuan ibu tentang pentingnya ASI eksklusif, ASI perah, penerapan ASI perah dan kesulitan selama bekerja mekanisme pertahanan terhadap pengaruh susu formula dan MP ASI dini, dan keberhasilan penerapan ASI Eksklusif. Tema kunjungan pada informan triangulasi yaitu pengetahuan tentang ASI eksklusif), pendapat pemberian ASI selama bekerja, pendapat tentang susu formula dan dampak bagi tumbuh kembang bayi, usaha yang telah dilakukan untuk mendukung ASI eksklusif, pendapat tentang keunggulan ASI, cuti dalam kerja, pojok ASI, ASI Perah, dan kebijakan yang dilakukan untuk mendukung pemberian ASI eksklusif bagi karyawan .

Makna yang peneliti dapatkan dari hasil penelitian ini adalah peneliti melihat adanya komitmen yang sangat baik dari informan untuk dapat menerapkan ASI eksklusif sehingga sampai kunjungan terakhir terhadap informan Utama bayi masih diberikan ASI secara eksklusif walaupun ad pengaruh dari luar untuk pemberian susu formula dan MP ASI.

\section{Daftar Pustaka}

[1] Marmi (2012). Asuhan neonatus, bayi, balita dan anak prasekolah. Yogyakarta: Pustaka Pelajar.

[2] Dinkes Jateng (2013). Profil Kesehatan Provinsi Jawa Tengah Tahun 2013, Semarang: Dinkes Jateng

[3] Polit DF, Hungler BP (2005). Nursing research : Principles \& Methods (Ed6). Philadelphia: Lippicott Williams \& Wilkins.

[4] Peraturan Pemerintah Republik Indonesia Nomor 33 Tahun 2012 Tentang Pemberian Air Susu Ibu Eksklusif

[5] Rahmawati (2010). Faktor-faktor yang Mempengaruhi Pemberian ASI Eksklusif pada Ibu Menyusui di
Kelurahan Pedalangan Kecamatan Banyumanik Kota Semarang. Departemen Ilmu Kesehatan Anak, Fakultas Kedokteran Indonesia Rumah Sakit Cipto Mangunkusumo, Jakarta

[6] Juliani, S. 2009. Faktor-Faktor yang Berhubungan dengan Pemberian ASI Eksklusif di Wilayah Kerja Puskesmas Binjai Estate. Skripsi. Medan: Fakultas Kesehatan Masyarakat. Universitas Sumatera Utara

[7] 1945, Undang-Undang Dasar 1945 pasal 28A Ayat 1, Republik Indonesia, Jakarta.

[8] Damayanti D (2010). Asyiknya minum ASI. Jakarta: PT. Gramedia Pustaka Utama.

[9] Khamzah, Siti N (2012). Segudang keajaiban ASI, Yogjakarta , FlashBook

[10] Abdullah, dkk, 2004. Pengambilan Keputusan pemberian ASI eksklusif kepada bayi di Kota Bogor, Media Gizi dan Keluarga, Juli 2004

[11] Reni Fahriani dkk (2013). Faktor yang mempengaruhi Pemberian ASI Ekklusif pada Bayi Cukup Bulan yang dilakukan IMD di salah satu Rumah Sakit Sayang Ibu di Jakarta. Departemen Ilmu Kesehatan Anak, Fakultas Kedokteran Indonesia Rumah Sakit Cipto Mangunkusumo, Jakarta

[12] Maria El, Yustina P, Wilhelmus. 2013. Faktor-faktor yang berhubungan dengan pemberian makanan prelakteal serta implikasinya terhadap berat badan bayi usia 0-6 bulan di Puskesmas Atambua Selatan. Ejournal.stiksintcarolus.ac.id

[13] Sri Astuti, Ari Indra S, Tina Dewi J. 2016. Pengaruh Pelatihan pemberian ASI eksklusif terhadap pengetahuan menyusui Kelompok Pendukung ASI di Desa Mekargalih dan Cipacing Kecamatan Jatinangor Kabupaten Sumedang. JSK Volume 1 Nomer 3 tahun 2016 